This item is the archived peer-reviewed author-version of:

\title{
Climate, communication and participation impacting commitment to change
}

\section{Reference:}

Rogiest Sofie, Segers Jesse, van Witteloostuijn Arjen.- Climate, communication and participation impacting commitment to change

Journal of organizational change management - ISSN 0953-4814 - 28:6(2015), p. 1094-1106

Full text (Publishers DOI): http://dx.doi.org/doi:10.1108/JOCM-06-2015-0101

Handle: http://hdl.handle.net/10067/1282260151162165141 


\title{
AN EMPIRICAL STUDY OF THE IMPACT OF CLIMATE, QUALITY CHANGE COMMUNICATION AND EMPLOYEE PARTICIPATION ON AFFECTIVE COMMITMENT TO CHANGE
}

\author{
Sofie E. Rogiest ${ }^{\mathrm{abc}}$, Jesse Segers ${ }^{\mathrm{ab}}$, and Arjen van Witteloostuijn ${ }^{\mathrm{ac}}$ \\ ${ }^{a}$ University of Antwerp \\ ${ }^{\mathrm{b}}$ Antwerp Management School \\ ${ }^{\mathrm{c}}$ Tilburg School of Economics and Management
}

Correspondence should be addressed to Sofie Rogiest (sofie.rogiest@uantwerpen.be), Antwerp Management School, Sint-Jacobsmarkt ç-13, 2000 Antwerpen, Belgium.

Acknowledgments. This research is largely funded by the European Commission as part of FP7 in the context of the COMPOSITE project (contract number 241918). 


\title{
AN EMPIRICAL STUDY OF THE IMPACT OF CLIMATE, QUALITY \\ CHANGE COMMUNICATION AND EMPLOYEE PARTICIPATION ON
}

\author{
AFFECTIVE COMMITMENT TO CHANGE
}

\begin{abstract}
Purpose - Through the combination of change process, context and content this paper aims to provide a deeper understanding of failure or success of organizational change. This study considers the effect of organizational climate on affective commitment to change simultaneously with quality change communication and employee participation during the change process, while controlling for perceived change impact.

Design/methodology/approach - The findings are based on 134 responses gathered through surveys in two police forces that recently underwent a merger.

Findings - First, quality change communication is the only process variable that directly impacts affective commitment to change. Second, our results indicate that an involvement-oriented climate positively affects affective commitment to change, mediated through quality change communication. Third, we find that employee participation reduces affective commitment to change in a high formalization climate.

Originality/value -First, the general understanding of the impact of climate on organizational change is very limited. Second, employee participation and quality change communication are generally studied together. We propose that both process variables each have their unique impact on attitudes towards change. Third, the interaction between organizational climate and both change process indicators, offers a practical approach on how to increase the success of organizational change.

Keywords: organizational change, affective commitment to change, organizational climate, procedural justice, employee participation, change communication, change management, policing environment, police, Belgium

Paper type Research paper
\end{abstract}




\section{Introduction}

Although failure rates of organizational change are estimated to be as high as two thirds of all initiatives (Beer \& Nohria, 2000; Burnes, 2004), change often remains the only constant in many organizations (Sorge \& van Witteloostuijn, 2004). The low success rate is frequently judged to be an implementation failure rather than a flaw of the change itself (Armenakis \& Harris, 2009; Klein \& Sorra, 1996; Kotter, 1995). While a failure of planned change may indeed have multiple causes, few are as critical as employees' attitudes toward change. The central role workers play should not be underestimated (Choi, 2011; Jones, Jimmieson, \& Griffiths, 2005; Meyer, Srinivas, Lal, \& Topolnytsky, 2007) and the active support of individuals is essential, especially during the implementation process (Ford, Weissbein, \& Plamondon, 2003; Self, Armenakis, \& Schraeder, 2007). Attitudes toward change have become a popular subject of scholarship, and many similar but distinct concepts have been introduced into the literature. Amongst these, a leading construct in the research on individual attitudes toward change is affective commitment to change (Choi, 2011), which has been associated with improved coping with change, lower turnover intentions and increased supportive behavior during organizational change (Jaros, 2010).

In line with Walker, Armenakis, and Bernerth's (2007) and Jacobs, van Witteloostuijn, Christe-Zeyse, and Polos' (2013) recommendations, we study change process, context and content combined, to improve our general understanding as to why and how organizations change. First, quality change communication and employee participation are introduced as two separate change process variables. Previous research primarily studied the combined impact of both variables, as they are situated within the concept of procedural justice (Caldwell, Herold, \&

Fedor, 2004; Korsgaard, Schweiger, \& Sapienza, 1995). Both variables, however, will require different efforts from organizations (Cotton, Vollrath, Froggatt, Lengnick-Hall, \& Jennings, 
1988). Hence, considering them separately will provide leaders useful insights into these influential processes (Bordia, Hunt, Paulsen, Tourish, \& DiFonzo, 2004). Second, it is important to increase our understanding of how well organizations are suited to cope with organizational change, as this is becoming a continuous process (Jones et al., 2005). Hence, our analysis includes organizational climate, as a context variable. Last, we consider perceived change impact as a control variable, since the outcome valence will have a considerable influence in and of itself (Fedor, Caldwell, \& Herold, 2006).

Our study offers at least three contributions to the organizational change literature. First, the general understanding of the impact of climate on organizational change is very limited (Jones et al., 2005; Lofquist, 2011). In our study, we include two different dimensions of climate: formalization and involvement. Both dimensions of climate have an inward focus, but a formalization climate is presented as an optimal structure for stable operations, while an involvement-oriented climate is more oriented toward flexibility (Patterson et al., 2005). Including these two dimensions of climate will provide a better view on the organizational context suitable for successful organizational change. Second, although both high-quality change communication and high employee participation will increase procedural fairness (Caldwell et al., 2004), both processes require different organizational capabilities. Hence, insight into the impact of both variables separately on attitudes toward change will benefit organizational practices. Third, the interaction between organizational climate and both change process indicators, offers a deeper understanding of the impact of organizational context on organizational change processes.

Below, we first briefly describe affective commitment to change as an individual-level outcome. Next, hypotheses concerning both change process variables and organizational climate are developed. Third, interaction effects of quality change communication and employee 
participation with two dimensions of climate are presented. Subsequently, we introduce our design, methodology and results. Last, we conclude with a discussion of our findings for future research and practice.

\section{The Relationship Between Communication, Participation and Commitment}

Commitment is considered to be one of the most important indicators in explaining employee behavior and desirable work-related outcomes in organizations (Choi, 2011). The definition of commitment has been generalized by Meyer and Herscovitch (2001), and is defined as "a force that binds an individual to a course of action of relevance to one or more targets" (p. 301). This makes the concept applicable to multiple foci, including organizational change. Based on this definition, commitment to change has been defined as "a force (mind-set) that binds an individual to a course of action deemed necessary for the successful implementation of a change initiative" (Herscovitch \& Meyer, 2002, p. 475). Herscovitch and Meyer (2002) propose a threefactor model of affective commitment to change. In our analyses, we study the antecedents of affective commitment to change, reflecting "a desire to provide support for the change based on a belief in its inherent benefits" (Herscovitch, \& Meyer, 2002, p. 475). Previous studies indicate the importance of affective commitment to change for supportive behavior during organizational change, higher job satisfaction and lower turnover intentions (Ford et al., 2003; Herscovitch \& Meyer, 2002; Jaros, 2010; Neves \& Caetano, 2009; Rafferty \& Restubog, 2010). In line with previous research, the current study focuses on this dimension (Conway \& Monks, 2008; Herold, Fedor, Caldwell, \& Liu, 2008; Neves \& Caetano, 2009).

Affective commitment to change develops when individuals recognize the value of organizational change. The way the organizational change is implemented will strongly influence 
affective commitment to change (Yilmaz, Ozgen, \& Akyel, 2013). High-quality change communication, is typically defined as accurate, timely and complete information addressing employee concerns (Miller \& Monge, 1986; Miller, Johnson, \& Grau, 1994), as well as offering opportunities for participation in decision-making are widely recommended strategies to increase involvement and value relevance, and as such impact commitment to change (Armenakis \& Bedeian, 1999; Beer \& Nohria, 2000; Choi, 2011; Herscovitch \& Meyer, 2002). Although both change processes will enhance perceptions of procedural justice (Caldwell et al., 2004; Korsgaard et al., 1995), we suggest that they will increase affective commitment to change in different ways. We argue that high-quality change communication will reduce uncertainty, and that high employee participation will increase the opportunity for voice and control over the outcome of the change.

First, organizational change implies great uncertainty and employees will devote much time to processes of sense-making (Weick, Sutcliffe, \& Obstfeld, 2005). The provided information reduces uncertainty (Bordia et al., 2004) and allows employees to prepare, which will enhance their positive perceptions about the change. Especially during organizational changes characterized by high uncertainty such as large transformations aimed at altering responsibilities, teams or locations, high-quality change communication will positively impact affective commitment to change (DiFonzo \& Bordia, 1998). Previous findings relate high-quality change communication to greater change acceptance, openness and support for the change (Allen, Jimmieson, Bordia, \& Irmer, 2007; Miller et al., 1994; Oreg, Vakola, \& Armenakis, 2011; Wanberg \& Banas, 2000).

Hypothesis la (Hla): High-quality change communication will positively relate to affective commitment to change. 
Second, the opportunity for voice, self-discovery and increased influence over the outcome of the change is facilitated by participation in decision-making. This will provide employees with the inherent motivation to support the change (Armenakis, Harris, \& Mossholder, 1993; Bordia et al., 2004; Caldwell et al., 2004; Gopinath \& Becker, 2000; Johnson-Cramer, Cross, \& Yan, 2003). Employee participation has been reported to relate to positive outcomes such as higher readiness and acceptance of change, and overall exhibited support for the change (Armenakis \& Bedeian, 1999; Holt, Armenakis, Feild, \& Harris, 2007; Oreg et al., 2011; Wanberg \& Banas, 2000). As employee participation and quality change communication influence attitudes toward change through different mechanisms, we propose that employee participation will partially contribute to affective commitment to change as well.

Hypothesis $1 b(H 1 b):$ High employee participation will positively relate to affective commitment to change.

\section{Formalization and involvement climate}

Organizational change cannot be separated from the organization in which the change occurs. Rather, organizational change should be seen as a process that emerges and evolves in the cultural, historical and political context of the organization (Pettigrew \& Whipp, 1991). In line with this observation, many researchers have looked into contextual factors such as positive experiences with previous changes (Devos, Vanderheyden, \& Van den Broeck, 2002), highquality relationships between employees and managers (Parish, Cadwallader, \& Busch, 2008), and effective leadership practices (Herold et al., 2008; Parish et al., 2008). Psychological climate 
represents an individual's perception of their work environment (James et al., 2008). These perceptions allow an employee to interpret events, predict possible outcomes and evaluate the appropriateness of their actions (Parker et al., 2003). In prior work, psychological climate has been found to be strongly related to affective variables at work, including organizational citizenship behavior (Ehrhart, 2004), innovation (Anderson \& West, 1998), and organizational commitment (McMurray, Scott, \& Pace, 2004). Additionally, previous research related an individual's perception of the organizational environment to readiness to accept and engage in organizational change (Armenakis, Bernerth, Pitts, \& Walker, 2007; Holt et al., 2007).

In the current study, we included two dimensions of climate, namely formalization and involvement, which are embedded in the broader competing values framework (Quinn \& Rohrbaugh, 1983). Each proposed dimension has a specific focus, and the combination of evaluations on each dimension will be different for each organization. As both dimensions have their own specific focus, they can be combined. Both formalization and an involvement-oriented climate share an inward focus. This is especially relevant when studying organizational change, as it emphasizes the relationship between employees and the tasks they perform, on the one hand, and the organization, on the other hand. A formalization climate refers to an organization that is "concerned with formal rules and procedures" (Patterson et al., 2005, p. 386). We argue that increased formalization will reduce affective commitment to change, since a formalization climate implies a focus on consolidation and continuity. A highly formalized organization is characterized by strict rules and procedures, and is oriented toward maintaining the status quo, especially apt in stable environments. In such a climate, employees view change as a threat and a challenge to the existing organization. This will reduce the perceived value and success of the change, and decrease affective commitment to change. In support of this reasoning, Eby, Adams, 
Russell, and Gaby (2000) report that flexible policies and procedures are positively related to employees' evaluations of whether their organization is ready to cope with change events.

Hypothesis $2 a(\mathrm{H} 2 \mathrm{a}):$ A high formalization climate will negatively relate to affective commitment to change.

In contrast, we expect that a high involvement-oriented climate will increase affective commitment to change. An involvement-oriented climate refers to an organization where "employees have considerable influence over decision-making” and which is characterized by "the free sharing of information throughout the organization" (Patterson et al., 2005, p. 386). Organizations with a high involvement-oriented climate are characterized by participation and empowerment. Hence, we propose that change initiatives will take into account and respect individuals' views, and stimulate affective commitment to change. Previous research indicates that climates of involvement, empowerment, resolving conflicts, and cooperation focused on employee well-being and commitment will increase employee satisfaction, commitment and motivation (Maynard, Mathieu, Marsh, \& Ruddy, 2007; Tesluk, Vance, \& Mathieu, 1999), and will positively influence their attitudes toward change (Brown \& Cregan, 2008; Eby et al., 2000; Jones et al., 2005; Schneider, Brief, \& Guzzo, 1996).

Hypothesis $2 b(\mathrm{H} 2 b):$ A high involvement-oriented climate will positively relate to affective commitment to change. 


\section{Quality change communication and employee participation as mediators}

We argue that both quality change communication and employee participation during a change process are useful mediating constructs to understand how organizational climate influences affective commitment to change. Psychological climate impacts the perceptions of supported and rewarded behaviors and practices. As such, this will direct and motivate employee efforts (Schneider et al., 1996). First, an organizational climate high in formalization focuses on rules and procedures as primary modus operandi. Leadership strives for stability and control, through formal information management, fact-based decision-making and targeted communication. The focus on formal rules and procedures aims to optimize communication, but does not foster participative decision-making (Jones et al., 2005). In a high formalization climate, we expect that there will be few opportunities for employee participation. In addition, employees will try to limit their involvement as this is not reinforced within the organization.

\section{Hypothesis $3 a(H 3 a):$ The negative effect of a high formalization climate on affective} commitment to change is fully mediated by employee participation.

In an organizational climate characterized by involvement, information is more broadly shared, and individual employees have more opportunities to participate (Miller et al., 1994). Employees are provided with opportunities to investigate, discuss and impact their environment. This organizational capability can fruitfully be applied during change initiatives, ensuring that correct and timely information is provided to individual employees, and that structures for participation are put in place. Moreover, the organizational context influences the expectations of individual employees, and hence their behavior. High-quality change communication and employee participation will be called for, as these practices are supported in the organization. 
This will increase the focus on these processes during organizational change initiatives. Previously, Eby et al. (2000) found that employees who perceive their environment as highly participative will be more likely to anticipate being involved in decisions during change initiatives.

Hypothesis $3 b(H 3 b):$ The positive effect of a high involvement-oriented climate on affective commitment to change is fully mediated by quality change communication and employee participation.

\section{Climate as a potential moderator}

The impact of quality change communication and employee participation will depend on the context in which these practices are implemented (Miller \& Monge, 1986; Raelin, 2012). Previously, scholars have emphasized the importance of a match between organizational culture and implementation method (Damanpour, 1991; Piderit, 2000). Lok, Hung, Walsh, Wang, and Crawford (2005), found that organizational alignment increased the effectiveness of improvement programs. Additionally, Lofquist (2011) demonstrated that a mismatch between organizational climate and implementation method contributes to the failure of organizational change. As climate defines the agreed set of accepted behaviors (Meyerson \& Martin, 1987), it will impact the effect of the change process variables on affective commitment to change. A high formalization climate emphasizes formal information management and precise communication. A high involvement-oriented climate stresses open communication as a way to foster morale and cohesion amongst employees (Jones et al., 2005). We propose that when an employee exhibits a certain behavior in a climate which is supportive, the impact will be higher. Both in high 
formalization and high involvement-oriented climates, high-quality change communication will be most effective and organizational sense-making can be optimized. Hence, we propose that the impact of high-quality change communication on affective commitment to change will increase.

Hypothesis $4 a(\mathrm{H} 4 \mathrm{a})$ : There is a positive interaction effect between a formalization climate and quality change communication. High-quality change communication particularly increases affective commitment to change in a high formalization climate. Hypothesis $4 b(H 4 b):$ There is a positive interaction effect between an involvementoriented climate and quality change communication. High-quality change communication particularly increases affective commitment to change in a high involvement-oriented climate.

With regards to decision-making processes, however, a highly formalized climate favors data-based decision-making, while a high involvement-oriented climate supports participative decision-making (Jones et al., 2005). In a highly formalized climate, employee participation does not fit within the organizational norms and will not be accepted. Hence, any effort spent on participation will not be rewarded, and might even be penalized. Therefore, we expect that the impact of employee participation on affective commitment to change will be negative in a high formalization climate. In contrast, employee participation is a key characteristic of decisionmaking in a high involvement-oriented climate. This behavior will be reinforced. Hence, we expect that in a high involvement environment, the effect of employee participation on affective commitment to change will increase. 
Hypothesis $5 a(\mathrm{H} 5 \mathrm{a})$ : There is a negative interaction effect between a formalization climate and employee participation. High employee participation particularly reduces affective commitment to change in a high formalization climate.

Hypothesis $5 b(H 5 b):$ There is a positive interaction effect between an involvementoriented climate and employee participation. High employee participation particularly increases affective commitment to change in a high involvement-oriented climate.

\section{Methodology}

This study tests the hypotheses associated with our theoretical model by collecting data through an employee survey in two different police organizations. To reduce common-method variance, a number of ex-ante steps were taken in de design of the study, as suggested by Chang, van Witteloostuijn, and Eden (2010). For multi-item Likert-scales, multiple endpoints were used (ranging from 4 to 7), as well as different formats in the form of reversed items, as proposed by Podsakoff, MacKenzie, Lee, and Podsakoff (2003). Additionally, the order of the items was randomized between constructs, and we included a complex set of constructs dealing with individual-level attitudes (affective commitment to change), change- specific processes (quality change communication and employee participation), and organizational-level characteristics (organizational climates). Moreover, moderation effects were estimated, which reduces the likelihood that individual respondents were guided by a mental model that correctly reflects the theorized relationships. In addition, an ex-post Harman's one-factor test was conducted (Podsakoff \& Organ, 1986), without detecting evidence of common-method variance.

\section{Sample}


The first organization is a local Belgian police force, with 158 employees. They are focused on neighborhood policing, reception, intervention, aid to victims, local investigations, maintaining public order, and traffic control. It was created nine months before the study by merging two adjacent police forces with the same responsibilities and tasks, but covering different geographical areas. The second organization is a support unit of a Belgian police force, with 20 employees. Their focus is primarily on providing technical, administrative and operational support to local police forces, and on coordinating national police operations. The support unit was created seven months before the study in a merger of two separate entities with the same responsibilities and tasks, but in adjacent regions. Both mergers intended to improve cooperation and increase knowledge transfer between two similar organizations, while minimizing individual impact by limiting changes in work units, responsibilities, tasks and locations. In both organizations we measured the psychological climate in the work units, as different leadership and responsibilities may vary and foster diverse climates. Employees not always worked in similar climates, nor did they receive the same levels of information and possibilities for participation, or experience a similar change impact.

In total, 178 surveys were distributed - 158 in the local police force and 20 in the support unit - of which 134 completed surveys were returned: 116 in the local police force and 18 in the support unit. This resulted in an overall response rate of 75.3 percent. Of all the respondents, 65.7 percent are male, 61.7 percent are younger than 45 years, 57.4 percent worked more than ten years for the police organization, and 78.5 percent was not in a leadership position. Regarding educational level, 38.4 percent had a bachelor's degree or higher, 16.0 percent finished supplementary secondary education, and the remaining 45.6 percent graduated from secondary schools or lower. Those who returned the survey were representative of the organization at large $(\mathrm{N}=178)$ with regards to gender (68\% male) and age (57.9\% younger than 45 years). 
Participants were asked to describe the impact of the merger on their personal job, and to respond to a series of questions regarding the change. Data were obtained through a survey in the name of a major academic institution, explaining that the questionnaire was conducted in the context of a research project on organizational change. In both organizations, the questionnaires were distributed and collected by the participating organization via a closed envelope to guarantee confidentiality. Anonymity was assured, respondents were informed that there were no right or wrong answers, and they were asked to answer as honestly as possible.

\section{Measures}

To ensure adequate measurement of each variable, previously established multi-item scales are used. Questionnaires were administered in the respondents' native language (Dutch). In line with Brislin's (1980) recommendations, questionnaires were first translated in Dutch by one of the publishing authors, followed by the back-translation by an independent researcher. The means, standard deviations and reliability estimates (Cronbach, 1951) for all of the study variables are reported in Table 1. As all reliabilities are above the threshold of .6, they are considered acceptable (Hair, Anderson, Tatham, \& Black, 1998). Unless mentioned otherwise, all items are rated on a seven-point Likert-type scale (from $1=$ strongly disagree to $7=$ strongly agree).

\section{[INSERT TABLE 1 ABOUT HERE]}

Affective commitment to change. Affective commitment to change was measured using the six-item affective commitment to change scale of Herscovitch and Meyer (2002). Example items are "I believe in the value of this change" and "This change serves an important purpose". 
Quality change communication. Quality change communication and employee participation were included as focal aspects of the organizational change processes. Quality change communication was assessed with the scale originally developed by Miller et al. (1994) and previously adapted by Wanberg and Banas (2000). The scale consists of four items. A sample item is "The information provided to me has adequately answered my questions about the changes".

Employee participation. Employee participation was measured with a three-item adapted scale, originally developed by Wanberg and Banas (2000). A sample item is "I have given input for the decisions being made about the future of the organization". Both employee participation in decision-making and change communication have previously been studied together as indicators of change fairness (Caldwell et al., 2004). Hence, we conducted an exploratory factor analysis to test whether they are separate constructs in our study. Principal axis factoring with varimax rotation on the seven items resulted in two factors, accounting for 75.50 percent of the variance. The four items assessing quality change communication loaded on one factor (factor loading $\geq .79$ ), and the three items assessing employee participation loaded on the second factor (factor loading $\geq .82$ ). None of the items had a loading of above .40 on both factors, and we conclude that both constructs are distinctly different (Tabachnick \& Fidell, 2001). The items and factor loadings are provided in Appendix.

Psychological climate. Two dimensions of climate were measured using the organizational climate measure, developed by Patterson et al. (2005). In the present study, respondents were presented with eleven randomized statements, measuring the level of formalization (five statements) and involvement (six statements) in their work unit. Respondents were asked to indicate the extent to which the statement is a correct description of the current work climate in their work unit (from $1=$ definitely false to $4=$ definitely true). Example items 
are: "It is considered extremely important here to follow the rules" (formalization climate) and "Management involve people when decisions are made that affect them" (involvement-oriented climate). Whereas change communication and the opportunity for employee participation will be dependent on the change agent leading the change initiative, the work unit climate will be defined by the work unit leader. Hence, when both leaders (change and work unit) are different, we expect there to be a variation between the psychological climate and the process indicators.

Control variables. Previous research indicates the importance of the perceived impact of the changes on change commitment (Fedor et al., 2006). Hence, perceived change impact for the affected work unit was included as a control variable in our analysis. This was measured using a four-item consequence of change scale of Caldwell et al. (2004). A sample item for this measure is "This change has made my unit less effective" (reverse coded). Ratings are on a five-point scale, ranging from 1 (strongly disagree) to 5 (strongly agree). Additionally, four demographic control variables were included. First, as older individuals are expected to be less positive about change (Posthuma \& Campion, 2009), age in years was added. Second, we controlled for management position $(0=$ no; $1=$ yes $)$, given that managers have better access to information and more opportunity to participate in the change process than non-managerial employees. Third, we controlled for organizational tenure as individuals with a long history within the organization may have more difficulty with organizational change $(0=\langle 10 \mathrm{y} ; 1=>10 \mathrm{y})$. Last, gender was examined for its potential relevance $(0=$ male; $1=$ female $)$, since the dominant presence of men in the police could limit the women employee participation during change, as a relative minority.

\section{Results}

Table 1 reports variable descriptive statistics (means and standard deviations) and zero-order correlations. The correlation between quality change communication and employee participation 
is moderate $(r=.40, p<.01)$, which was expected since they both fit within the broader concept of change fairness. Quality change communication and employee participation positively relate to affective commitment to change $(r=.44$ and $r=.43, p<.01)$, which is in line with Hypotheses 1a and 1b. Next, involvement-oriented climate positively correlates with affective commitment to change $(r=.46, p<.01)$, possibly supporting Hypothesis $2 \mathrm{~b}$. Last, both quality change communication and employee participation correlate significantly with involvement-oriented climate $(r=.49$ and $r=.34, p<.01)$, indicating possible support for Hypothesis $3 \mathrm{~b}$. With regards to the control variables, perceived change impact correlates positively with quality change communication $(r=.35, p<.01)$, employee participation $(r=.30, p<.01)$, involvement-oriented climate $(r=.63, p<.01)$ and affective commitment to change $(r=.56, p<.01)$. This suggests that using this measure as a control variable will result in a conservative test of our hypotheses.

Six hierarchical linear multiple regression analyses are conducted to test the direct, mediation and moderation effects of quality change communication, employee participation and psychological climate on affective commitment to change. The results are reported in Table 2.

\section{[INSERT TABLE 2 ABOUT HERE]}

To ensure appropriateness of the ordinary least square models (OLS), we tested for linearity of the relationships, independence of the explanatory variables, normality of the distributions, constant variation of the errors, and possible outliers influencing the results. First, for all six models, the plots show that estimating a linear relationship between the explanatory and dependent variable is appropriate. Next, all variance inflation factors are below two for all variables in the different models (with the exception of the moderation coefficients), indicating that multicollinearity is not an issue. Third, the normal probability plots show a reasonable fit, confirming that the assumption of normality is satisfied. Fourth, residual plots versus fitted values give a random pattern, validating the assumption of constant error variation. Finally, only one 
influential outlier was identified. Since no irregularities in the respondent's answers were found, this was considered to be a legitimate case. As the probability that this single outlier would influence the validity of the model was considered limited, this entry remained in the data. All six models provide a good fit for the data, with an adjusted $\mathrm{R}^{2}$ ranging from .33 for Model $3 \mathrm{~b}$ to .51 for Models 1, 3 and 4. An overview of the results is presented in Figure 1.

\section{[INSERT FIGURE 1 ABOUT HERE]}

The results indicate that quality change communication contributes significantly and partially to affective commitment to change $(\beta=.26, p<.01)$, implying that Hypothesis 1a is supported. There is no significant contribution of employee participation to affective commitment to change, however. Hence, Hypothesis $1 \mathrm{~b}$ is not supported. Model 2, testing Hypotheses $2 \mathrm{a}$ and $2 \mathrm{~b}$, reveals that an involvement-oriented climate is significantly positively associated with affective commitment to change $(\beta=.20, p<.05)$. Hence, Hypothesis $2 \mathrm{~b}$ is fully supported. Individuals who perceive a high involvement work climate report high affective commitment to change. Comparison of Model 2's adjusted $R^{2}(.47)$ with Model $1\left(R^{2}=.41\right)$ suggest that quality change communication and employee participation are more important than the climate variables in explaining affective commitment to change. No support is found for the relationship between formalization climate $(\mathrm{H} 2 \mathrm{a})$ and affective commitment to change.

In Models 3, 3a and 3b, we apply the criteria defined by Baron and Kenny (1986) to analyze if quality change communication and employee participation mediate the relationship between psychological climate and affective commitment to change. To test the overall significance of the mediation we use bootstrapping as recommended by Fritz and MacKinnon (2007). This procedure has been suggested for testing the significance of indirect effects, especially with smaller sample sizes, because it comes without assumptions regarding underlying sampling distributions (Shrout \& Bolger, 2002). Using the 'INDIRECT' SPSS macro of Preacher 
and Hayes (2008), we construct bias-corrected confidence intervals around the product coefficient of the indirect (mediated) effect. The product coefficient is based on the size of the relationship between an involvement-oriented climate, as the explanatory variable, and quality change communication and employee participation, as the mediating variables, and the relationship between the latter two constructs and affective commitment to change. In support of Hypothesis $3 b$, we find that quality change communication fully mediates the relationship between an involvement-oriented climate and affective commitment to change, as detailed in Figure 2 . The indirect effect $(\beta=.11, \mathrm{p}<.05)$ can be attributed entirely to quality change communication. The indirect effect through employee participation is not significant, implying that our results do not support Hypothesis 3a.

\section{[INSERT FIGURE 2 ABOUT HERE]}

With regards to the moderating effect of climate on the relationship between the two change process variables and affective commitment to change, we find marginal support for Hypothesis 5a, as illustrated in Figure 3A. The results show that the interaction between employee participation and formalization climate negatively and significantly impacts affective commitment to change $(\beta=.86, \mathrm{p}<.10)$. We probed this interaction to define the JohnsonNeyman significance regions (Bauer \& Curran, 2005; Hayes, 2012). Figure 3B shows the region for which the interaction between employee participation and formalization climate is significant i.e., when both 95 percent bootstrap confidence intervals are above or below zero. In our sample, the marginal effect of employee participation on affective commitment to change is significant for 36.2 percent of the respondents, who report a formalization climate below 2.58 on a 5-point scale. Below this threshold, the higher the formalization climate, the more employee participation will reduce affective commitment to change. No support was gained for $\mathrm{H} 4 \mathrm{a}, \mathrm{H} 4 \mathrm{~b}$ and $\mathrm{H} 5 \mathrm{~b}$. 


\section{Contributions and Implications for Research and Practice}

Employee commitment and motivation is a critical factor for the success of change initiatives (Oreg, Michel, \& By, 2013), and this study focuses on antecedents of affective commitment to change. We examined the impact of two dimensions of organizational climate, and studied the interaction with quality change communication and employee participation. Outcomes from linear multiple regression analyses of a sample of 134 Belgian police officers demonstrate that an involvement-oriented climate enhances affective commitment to change, and that this effect is fully mediated by quality change communication. Additionally, we find that employee participation reduces affective commitment to change in a highly formalized climate. Contrary to our expectations, formalization climate and employee participation do not directly impact affective commitment to change. Our hypotheses on the interaction between an involvement-oriented climate and employee participation, as well as our propositions that both dimensions of climate would moderate quality change communication are not confirmed. Below, we offer explanations for non-expected results, and discuss implications for research and practice.

First, the lack of a significant direct effect of employee participation on affective commitment to change could be dependent on our operationalization of employee participation. We consider quality change communication as a separate aspect of the change process, although greater access to information has been highlighted as a benefit of employee participation (Holt et al., 2007). Indeed, previous studies reporting positive results of participation did not single out the effects of improved quality change communication (Amiot, Terry, Jimmieson, \& Callan, 2006; Bouckenooghe, Devos, \& Van den Broeck, 2009; Holt et al., 2007; Lok et al., 2005). Post- 
hoc analyses provide some support for this explanation. The results from bootstrapping (Fritz \& MacKinnon, 2007) show that the direct effect of employee participation is fully mediated by quality change communication. Hence, this suggests that although employee participation offers the opportunity to influence the outcome of the change, our respondents particularly value that their questions about the change are better answered thanks to their participation in the change process. To provide more insight into this dynamic, future research could include increased control and reduced uncertainty as intervening mechanisms.

Additionally, the lack of direct effect of employee participation on affective commitment to change might be explained by the timing of employee participation. As we surveyed the degree of perceived participation after the implementation, it is realistic that workers refer mainly to their involvement during the later phases of the project. Previous research indicates that the impact of participation will differ depending on the change phase. According to Johnson-Cramer et al. (2003), employee involvement early in the design phase contributes considerably more to commitment than in a later stage of the implementation process. Likewise, it is likely that employees refer to the communication during the later phases of the project although Melkonian, Monin, and Noorderhaven (2011) found in their longitudinal study that procedural justice only became an predictor of employee's willingness to cooperate in the change after one year. Both studies, however, underscore the importance of timing, and we propose that future studies use a longitudinal design. Furthermore, one could expect that individuals in different roles (first-line manager, change agent, target group, communication expert, ...) may feel different toward the change. Hence, studies focusing on change communication and employee participation, would benefit from separating different roles during organizational change.

Second, our results do not confirm our assumption that formalization climate negatively impacts affective commitment to change. Although theory generally predicts this negative 
relationship, some researchers have emphasized the need of a clear purpose and explicit work procedures, inherent to a highly formalized climate, for a successful introduction of organizational change (Ettlie, Bridges, \& O'Keefe, 1984; Evan \& Black, 1967). These contradicting mechanisms might explain our lack of significant results. Future research could study the underlying mechanisms to provide a deeper understanding of the impact of formalization climate on attitudes toward change. Finally, of the hypothesized interactions, our results only deliver limited support for the fit hypotheses. Only the interaction between employee participation and formalization climate was marginally significant. A possible reason for the lack of findings is that other moderating variables are more relevant, such as change phase (Isabella, 1990), content (Armenakis \& Bedeian, 1999) or pacing (Amis, Slack, \& Hinings, 2004). Alternatively, as our sample consists of two police organizations, the variation in climate could be too limited. Previously, studies in both police organizations and public organizations found a strong focus on formalization and hierarchy, which might have impacted our results (Ford et al., 2003; Greene, 2000; Parker \& Bradley, 2000).

Overall, these findings have implications both for scholarship and practice. For researchers, on the one hand, our findings indicate that although employee participation has been advocated as one of the key factors associated with successful organizational change, the effect of high-quality change communication during organizational change might be more important. Future research could include the different mechanisms through which employee participation impact attitudes toward change to confirm our findings in different settings. Additionally, our results highlight the relevance of climate as a contextual variable during organizational change, both as an antecedent and a moderator of change-specific processes.

For practitioners, on the other hand, our findings call for an integrative approach to organizational transformations. The current budgetary challenges in police organizations, as in 
most organizations, create additional constraints for HR practitioners. Their added value is analyzed in detail and administrative HR functions are, as much as possible, automated and outsourced. Other functions such as employee evaluation and mentoring are being delegated to the functional departments (while supported by HR professionals). This creates the opportunity for HR to focus on other roles relevant during organizational change. In the role of change champion (Ulrich, Younger, Brockbank, \& Ulrich, 2013), HR professionals can function as a sounding board, and coach change leaders to optimize the installation and institutionalization of the change. High quality change communication should be their first concern, as our results demonstrate. Clear, concise and timely information will increase employee attitudes towards change. Human resources professionals can be the ears and eyes in the organization and provide the change leaders with feedback on the effectiveness of their communication. They can also provide support with regards to employee participation. Our results show that, overall, workers appreciate these forums, although they especially seem to value the improved communication rather than the increased influence over the decisions. Implementing employee participation, however, should be approached carefully, as our results show that in strongly formalized climates, employee participation might decrease affective commitment to change. As such, HR professionals can assist change leaders in defining the appropriate participation approach and in setting the correct expectations.

In the role of capacity builder (Ulrich et al., 2013), HR professionals can start to create a high-involvement climate irrespective of any current changes. The study of Farndale, Van Ruiten, Kelliher, and Hope-Hailey (2011) already demonstrated the added value in terms of increased commitment to the organization. In our study we broaden the benefits of a similar climate to affective commitment to change. A similar climate will be supportive during changes, as communication processes will be embedded in the organization, and employees will have a better 
view on the goal and the reason for the changes. Additionally, the organizational communication processes will be installed and can be used during organizational change. Our inclusion of both psychological climate and change process variables, allows us to offer insights in two of the three domains that have the greatest impact on business performance (Ulrich et al., 2013): aligning culture and practices and sustaining change.

\section{Study limitations and suggestions for further research}

As any study, this research has strengths as well as limitations, which suggest avenues for further research. First, our study looks at the same type of organizational change in two similar professional organizations. This focus excludes the potential influence of external industry factors, enabling a direct analysis of the relationship between internal context, change process, and affective commitment to change. On the negative side, the focus on mergers in police organizations entails that caution should be exercised in generalizing these findings to other contexts. Hence, our study has to be replicated in other organizations and professions. Second, although ex-ante measures are taken to limit the risk that common-method variance artificially inflates correlations, independent and dependent variables are measured from the same singleinformant source. Hence, common-method variance cannot completely be ruled out. In future work, it would be useful to include outcome data from other sources.

Third, causality cannot be tested in the current study, due to the cross-sectional design. Reciprocal relations could be found between the variables in the model. One could state that individuals, who are more committed to change, will report higher quality change communication and higher employee participation. They may perceive to be better informed (as a way to reduce cognitive dissonance) or may perceive to have been part of the decision making (to feel part of a 
successful endeavor). Similarly, one could envision that affective commitment to change alters the perceived organizational climate. Employees highly committed to the change may perceive the climate as more supportive of organizational change, and hence be more involvementoriented. Additionally, one could consider that climate evolves, and that the answers of the employees refer to the climate at a different point in time. Climate, however, is based on inferences of the employees, which are based on policies, practices, routines and procedures in the organization. As such, climate encompasses existing practices across diverse organizational activities. Because of the diversity and the implicit nature of these practices, the climate of an organization is very difficult to alter (Schneider et al., 1996). The changes in the current study were company-wide, but did not target to alter the level of involvement-orientation or formalization. Hence, we expect that alterations in climate, if they occurred, would have been small and would have had a limited impact on the results. In future research, longitudinal analysis would increase the robustness of our findings by explicitly testing for causalities and time-effects. Additionally, scholars found reciprocal relations between psychological climate and affective variables such as organizational well-being and job satisfaction (James et al., 2008). Future studies could investigate if this reciprocity also exists in the context of organizational change.

Fourth, it would be interesting to study the impact of organizational climate, in addition to psychological climate, in a multi-level study. Fifth, no significant relationships were found with respect to the impact of formalization climate, possibly due to the high climate strength in our pair of police organizations. A broader study including a multitude of organizational climates might find relationships, confirming or rejecting our hypotheses. Last, only a limited number of individual characteristics were included in our study. Future studies may, for example, include individual orientations toward change or leadership, as these can define individual expectation patterns which influence the success of organizational change. 


\section{REFERENCES}

Allen, J., Jimmieson, N. L., Bordia, P., \& Irmer, B. E. (2007). Uncertainty during organizational change: Managing perceptions through communication. Journal of Change Management, 7(2), 187-210.

Amiot, C. E., Terry, D. J., Jimmieson, N. L., \& Callan, V. J. (2006). A longitudinal investigation of coping processes during a merger: Implications for job satisfaction and organizational identification. Journal of Management, 32(4), 552-574.

Amis, J., Slack, T., \& Hinings, C. R. (2004). The pace, sequence, and linearity of radical change. Academy of Management Journal, 47(1), 15-39.

Anderson, N. R., \& West, M. A. (1998). Measuring climate for work group innovation: Development and validation of the team climate inventory. Journal of Organizational Behavior, 19(3), 235-258.

Armenakis, A. A., \& Bedeian, A. G. (1999). Organizational change: A review of theory and research in the 1990s. Journal of Management, 25(3), 293-315.

Armenakis, A. A., Bernerth, J. B., Pitts, J. P., \& Walker, H. J. (2007). Organizational change recipients' beliefs scale : Development of an assessment instrument. Journal of Applied Behavioral Science, 43(4), 481-505.

Armenakis, A. A., \& Harris, S. G. (2009). Reflections: Our journey in organizational change research and practice. Journal of Change Management, 9(2), 127-142.

Armenakis, A. A., Harris, S. G., \& Mossholder, K. W. (1993). Creating readiness for organizational change. Human Relations, 46(6), 681-703.

Baron, R. A., \& Kenny, D. A. (1986). The Moderator-mediator variable distinction in social psychological research: Conceptual, strategic, and statistical considerations. Journal of Personality and Social Psychology, 51(6), 1173-1182.

Bauer, D. J., \& Curran, P. J. (2005). Probing interactions in fixed and multilevel regression: Inferential and graphical techniques. Multivariate Behavioural Research, 40(3), 373-400.

Beer, M., \& Nohria, N. (2000). Resolving the Tension between Theories E and O of Change. In M. Beer \& N. Nohria (Eds.), Breaking the Code of Change. Boston: Harvard Business School Press.

Bordia, P., Hunt, E., Paulsen, N., Tourish, D., \& DiFonzo, N. (2004). Uncertainty during organizational change: Is it all about control? European Journal of Work and Organizational Psychology, 13(3), 345-365.

Bouckenooghe, D., Devos, G., \& Van den Broeck, H. (2009). Organizational change questionnaire. Climate of change, processes, and readiness: Development of a new instrument. Journal of Psychology, 143(6), 559-599.

Brislin, R. W. (1980). Translation and content analysis of oral and written material. In H. C. Triandis \& J. W. Berry (Eds.), Handbook of Cross-Cultural Psychology (Vol. 2, pp. 137-164). Boston, MA Allyn and Bacon.

Brown, M., \& Cregan, C. (2008). Organizational change cynicism: The role of employee involvement. Human Resource Management, 47(4), 667-686.

Burnes, B. (2004). Kurt Lewin and the planned approach to change: A re-appraisal. Journal of Management Studies, 41(6), 977-1002.

Caldwell, S. D., Herold, D. M., \& Fedor, D. B. (2004). Toward an understanding of the relationships among organizational change, individual differences, and changes in person-environment fit: A crosslevel study. Journal of Applied Psychology, 89(5), 868-882.

Chang, S.-J., van Witteloostuijn, A., \& Eden, L. (2010). From the editors: Common method variance in international business research. Journal of International Business Studies, 41, 178-184.

Choi, M. (2011). Employees' attitudes toward organizational change: A literature review. Human Resource Management, 50(4), 479 - 500. 
Conway, E., \& Monks, K. (2008). HR practices and commitment to change: An employee-level analysis. Human Resource Management Journal, 18(1), 72-89.

Cotton, J. L., Vollrath, D. A., Froggatt, K. L., Lengnick-Hall, M. L., \& Jennings, K. R. (1988). Employee participation: Diverse forms and different outcomes. Academy of Management Review, 13(1), 822.

Cronbach, L. J. (1951). Coefficient alpha and the internal structure of tests. Psychometrika, 16(3), 297334.

Damanpour, F. (1991). Organizational innovation: A meta-analysis of effects of determinants and moderators. Academy of Management Journal, 34(3), 555-590.

Devos, G., Vanderheyden, K., \& Van den Broeck, H. (2002). A Framework for assessing commitment to change. Process and context variables of organizational change. working paper.

DiFonzo, N., \& Bordia, P. (1998). A tale of two corporations: Managing uncertainty during organizational change. Human Resource Management, 37(3-4), 295-303.

Eby, L. T., Adams, D. M., Russell, J. E., \& Gaby, S. H. (2000). Perceptions of organizational readiness for change: Factors related to employees' reactions to the implementation of team-based selling. Human Relations, 53(3), 419-442.

Ehrhart, M. G. (2004). Leadership and procedural justice climate as antecedents of unit-level organizational citizenship behavior. Personnel Psychology, 57(1), 61-94.

Ettlie, J. E., Bridges, W. P., \& O'Keefe, R. D. (1984). Organization strategy and structural differences for radical versus incremental innovation. Management Science, 30(6), 682-695.

Evan, W. M., \& Black, G. (1967). Innovation in business organizations: some factors associated with success or failure of staff proposals. Journal of Business, 40(4), 519-530.

Farndale, E., Van Ruiten, J., Kelliher, C., \& Hope-Hailey, V. (2011). The influence of perceived employee voice on organizational commitment: An exchange perspective. Human Resource Management, 50(1), 113-129.

Fedor, D. B., Caldwell, S., \& Herold, D. M. (2006). The effects of organizational changes on employee commitment: A multilevel investigation. Personnel Psychology, 59(1), 1-29.

Ford, J. K., Weissbein, D. A., \& Plamondon, K. E. (2003). Distinguishing organizational from strategy commitment: Linking officers' commitment to community policing to job behaviours and job satisfaction. Justice Quarterly, 20(1), 159-186.

Fritz, M. S., \& MacKinnon, D. P. (2007). Required sample size to detect the mediated effect. Psychological Science, 18(3), 233-239.

Gopinath, C., \& Becker, T. E. (2000). Communication, procedural justice, and employee attitudes: relationships under conditions of divestiture. Journal of Management, 26(1), 63-83.

Greene, J. R. (2000). Community policing in America: Changing nature, structure, and function of the police. Criminal Justice, 3, 299-363.

Hair, J. F. J., Anderson, R. E., Tatham, R. L., \& Black, W. C. (1998). Multivariate Data Analysis (5th ed). Englewood Cliffs, NJ: Prentice Hall.

Hayes, A. F. (2012). PROCESS: A versatile computational tool for observed variable mediation, moderation, and conditional process modeling. [White paper]. Retrieved from http://www.afhayes.com/public/process2012.pdf.

Herold, D. M., Fedor, D. B., Caldwell, S., \& Liu, Y. (2008). The effects of transformational and change leadership on employees' commitment to a change: A multilevel study. Journal of Applied Psychology, 93(2), $346-357$.

Herscovitch, L., \& Meyer, J. P. (2002). Commitment to organizational change: Extension of a threecomponent model. Journal of Applied Psychology, 87(3), 474-487.

Holt, D. T., Armenakis, A. A., Feild, H. S., \& Harris, S. G. (2007). Readiness for organizational change : The systematic development of a scale. Journal of Applied Behavioral Science, 43(2), 232-255. 
Isabella, L. A. (1990). Evolving interpretations as a change unfolds. How managers construe key organizational events. Academy of Management Journal, 33(1), 7-41.

Jacobs, G., Van Witteloostuijn, A., Christe-Zeyse, J., \& Polos, L. (2013). A Theoretical Framework of Organizational Change. Journal of Organizational Change Management, 26(5), 2-2.

James, L. R., Choi, C. C., Ko, C.-H. E., McNeil, P. K., Minton, M. K., Wright, M. A., \& Kim, K.-i. (2008). Organizational and psychological climate: A review of theory and research. European Journal of Work and Organizational Psychology, 17(1), 5-32.

Jaros, S. (2010). Commitment to organizational change: A critical review. Journal of Change Management, 10(1), 79-108.

Johnson-Cramer, M. E., Cross, R. L., \& Yan, A. (2003). Sources of fidelity in purposive organizational change: Lessons from a re-engineering case. Journal of Management Studies, 40(7), 1837-1870.

Jones, R. A., Jimmieson, N. L., \& Griffiths, A. (2005). The impact of organizational culture and reshaping capabilities on change implementation success: The mediating role of readiness for change. Journal of Management Studies, 42(2), 361-386.

Klein, K. J., \& Sorra, J. S. (1996). The Challenge of Innovation Implementation. Academy of Management Review, 21(4), 1055-1080.

Korsgaard, M. A., Schweiger, D. M., \& Sapienza, H. J. (1995). Building commitment, attachment, and trust in strategic decision-making teams: The role of procedural justice. Academy of Management Journal, 38(1), 60-84.

Kotter, J. P. (1995). Leading change: Why transformation efforts fail. Harvard Business Review, 73(2), 5967.

Lofquist, E. A. (2011). Doomed to fail: A case study of change implementation collapse in the Norwegian civil aviation industry. Journal of Change Management, 11(2), 223-243.

Lok, P., Hung, R. Y., Walsh, P., Wang, P., \& Crawford, J. (2005). An integrative framework for measuring the extent to which organizational variables influence the success of process improvement programmes. Journal of Management Studies, 42(7), 1357-1381.

Maynard, M. T., Mathieu, J. E., Marsh, W. M., \& Ruddy, T. M. (2007). A multilevel investigation of the influences of employees' resistance to empowerment. Human Performance, 20(2), 147-171.

McMurray, A. J., Scott, D. R., \& Pace, R. W. (2004). The relationship between organizational commitment and organizational climate in manufacturing. Human Resource Development Quarterly, 15(4), 473-488.

Melkonian, T., Monin, P., \& Noorderhaven, N. G. (2011). Distributive justice, procedural justice, exemplarity, and employees' willingness to cooperate in $M \& A$ integration processes: An analysis of the Air France-KLM merger. Human Resource Management, 50(6), 809-837.

Meyer, J. P., \& Herscovitch, L. (2001). Commitment in the workplace: Toward a general model. Human Resource Management Review, 11(3), 299-326.

Meyer, J. P., Srinivas, E. S., Lal, J. B., \& Topolnytsky, L. (2007). Employee commitment and support for an organizational change: Test of the three-component model in two cultures. Journal of Occupational \& Organizational Psychology, 80(2), 185-211.

Meyerson, D., \& Martin, J. (1987). Cultural change: An integragion of three different views. Journal of Management Studies, 24(6), 623-647.

Miller, K. I., \& Monge, P. R. (1986). Participation, satisfaction, and productivity: A meta-analytic review. Academy of Management Journal, 29(4), 727-753.

Miller, V. D., Johnson, J. R., \& Grau, J. (1994). Antecedents to willingness to participate in a planned organizational change. Journal of Applied Communication Research, 22, 59-80.

Neves, P., \& Caetano, A. (2009). Commitment to change: Contributions to trust in the supervisor and work outcomes. Group \& Organization Management, 34(6), 623-644. 
Oreg, S., Michel, A., \& By, R. T. (2013). The Psychology of Organizational Change: Viewing Change from the Employee's Perspective. New York: Cambridge University Press.

Oreg, S., Vakola, M., \& Armenakis, A. (2011). Change recipients' reactions to organizational change: A 60year review of quantitative studies. Journal of Applied Behavioral Science, 47(4), 461-524.

Parish, J. T., Cadwallader, S., \& Busch, P. (2008). Want to, need to, ought to: Employee commitment to organizational change. Journal of Organizational Change Management, 21(1), 32-52.

Parker, C. P., Baltes, B. B., Young, S. A., Huff, J. W., Altmann, R. A., LaCost, H. A., \& Roberts, J. E. (2003). Relationships between psychological climate perceptions and work outcomes: A meta-analytic review. Journal of Organizational Behavior, 24(4), 389-416.

Parker, R., \& Bradley, L. (2000). Organisational culture in the public sector. Evidence from six organisations. International Journal of Public Sector Management, 13(2), 125-141.

Patterson, M. G., West, M. A., Shackleton, V. J., Dawson, J. F., Lawthom, R., Maitlis, S., Robinson, D. L., \& Wallace, A. M. (2005). Validating the organizational climate measure: links to managerial practices, productivity and innovation. Journal of Organizational Behavior, 26(4), 379-408.

Pettigrew, A. M., \& Whipp, R. (1991). Managing Change for Competitive Success. Cambridge, MA: Blackwell.

Piderit, S. K. (2000). Rethinking resistance and recognizing ambivalence: A multidimensional view of attitudes toward an organizational change. Academy of Management Review, 25(4), 783-794.

Podsakoff, P. M., MacKenzie, S. B., Lee, J.-Y., \& Podsakoff, N. P. (2003). Common method biases in behavioral research: A critical review of the literature and recommended remedies. Journal of Applied Psychology, 88(5), 879-903.

Podsakoff, P. M., \& Organ, D. W. (1986). Self-reports in organizational research: Problems and prospects. Journal of Management, 12(4), 531-544.

Posthuma, R. A., \& Campion, M. A. (2009). Age stereotypes in the workplace: Common stereotypes, moderators, and future research directions. Journal of Management, 35(1), 158-188.

Preacher, K. J., \& Hayes, A. F. (2008). Asymptotic and resampling strategies for assessing and comparing indirect effects in multiple mediator models. Behavior Research Methods, 40(3), 879-891.

Quinn, R. E., \& Rohrbaugh, J. (1983). A spatial model of effectiveness criteria: Towards a competing values approach to organizational analysis. Management Science, 29(3), 363-377.

Raelin, J. A. (2012). Dialogue and deliberation as expressions of democratic leadership in participatory organizational change. Journal of Organizational Change Management, 25(1), 7-23.

Rafferty, A. E., \& Restubog, S. L. D. (2010). The impact of change process and context on change reactions and turnover during a merger. Journal of Management, 36(5), 1309-1338.

Schneider, B., Brief, A. P., \& Guzzo, R. A. (1996). Creating a climate and culture for sustainable organizational change. Organizational Dynamics, 24(4), 7-19.

Self, D. R., Armenakis, A. A., \& Schraeder, M. (2007). Organizational change content, process, and context: A simultaneous analysis of employee reactions. Journal of Change Management, 7(2), 211-229.

Shrout, P. E., \& Bolger, N. (2002). Mediation in experimental and nonexperimental studies: New procedures and recommendations. Psychological Methods, 7(4), 422-445.

Sorge, A., \& van Witteloostuijn, A. (2004). The (non)sense of organizational change: An essai about universal management hypes, sick consultancy metaphors, and healthy organization theories. Organization Studies, 25(7), 1205-1231.

Tabachnick, B. G., \& Fidell, L. S. (2001). Using Multivariate Statistics. New York: HarperCollins College Publishers.

Tesluk, P. E., Vance, R. J., \& Mathieu, J. E. (1999). Examining employee involvement in the context of participative work environments. Group \& Organization Management, 24(3), 271-299. 
Ulrich, D., Younger, J., Brockbank, W., \& Ulrich, M. D. (2013). The state of the HR profession. Human Resource Management, 52(3), 457-471.

Walker, H. J., Armenakis, A. A., \& Bernerth, J. B. (2007). Factors influencing organizational change efforts. An integrative investigation of change content, context, process and individual differences. Journal of Organizational Change Management, 20(6), 761-773.

Wanberg, C. R., \& Banas, J. T. (2000). Predictors and outcomes of openness to changes in a reorganizing workplace Journal of Applied Psychology, 85(1), 132-142

Weick, K. E., Sutcliffe, K. M., \& Obstfeld, D. (2005). Organizing and the process of sensemaking. Organization Science, 16(4), 409-421.

Yilmaz, S., Ozgen, H., \& Akyel, R. (2013). The impact of change management on the attitudes of Turkish security managers towards change. Journal of Organizational Change Management, 26(1), 117138. 
Table 1: Means, Standard Deviations, Reliabilities, and Intercorrelations

\begin{tabular}{lcccccccc}
\hline & $\mathrm{M}$ & $\mathrm{SD}$ & 1 & 2 & 3 & 4 & 5 & 6 \\
\hline 1. Perceived change impact & 3.24 & 1.46 & $(.80)$ & & & & & \\
2. Quality change communication & 4.05 & 1.60 & $.35^{\star *}$ & $(.89)$ & & & & \\
3. Employee participation & 2.96 & 1.59 & $.30^{\star *}$ & $.40^{\star *}$ & $(.82)$ & & & \\
4. Formalization climate & 2.86 & 0.52 & .03 & .07 & $.05^{+}$ & $(.65)$ & & \\
5. Involvement-oriented climate & 2.31 & 0.75 & $.63^{* *}$ & $.49^{* *}$ & $.34^{* *}$ & .1 & $(.87)$ & \\
6. Affective commitment to change & 3.36 & 1.74 & $.56^{* *}$ & $.44^{\star *}$ & $.43^{* *}$ & -.09 & $.46^{* *}$ & $(.92)$ \\
\hline
\end{tabular}

Note. Alpha coefficients are presented on the diagonal in parentheses

${ }^{\dagger} p<.10,{ }^{*} p<.05$ and ${ }^{* *} p<.01$. 


\section{Table 2: Results from hierarchical linear regression}

\begin{tabular}{|c|c|c|c|c|c|c|}
\hline \multirow[b]{2}{*}{ Variable } & \multicolumn{4}{|c|}{ Affective commitment to change } & \multirow{2}{*}{$\begin{array}{l}\text { Quality change } \\
\text { com- } \\
\text { munication } \\
\text { Mod. 3a }\end{array}$} & \multirow{2}{*}{$\begin{array}{c}\text { Employee } \\
\text { participation } \\
\text { Mod. 3b }\end{array}$} \\
\hline & Mod. 1 & Mod. 2 & Mod. 3 & Mod. 4 & & \\
\hline Step 1 & & & & & & \\
\hline Organization & $.24^{\star *}$ & $.16^{*}$ & $.22^{* *}$ & $.21^{* *}$ & $-.30^{\star *}$ & .18 \\
\hline Gender & $-.13^{+}$ & $-.13^{+}$ & $-.13^{+}$ & -.12 & .03 & -.04 \\
\hline Age & .10 & -.03 & -.09 & -.11 & .16 & $.17^{\dagger}$ \\
\hline Organizational tenure & $-.17^{\star}$ & $-.25^{\star \star}$ & $-.18^{*}$ & $-.18^{*}$ & $-.20^{*}$ & $-.17^{\dagger}$ \\
\hline Management function & $.14^{+}$ & $.26^{\star *}$ & $.14^{+}$ & $.14^{\dagger}$ & $.27^{\star *}$ & $.40^{\star *}$ \\
\hline $\begin{array}{l}\text { Change impact } \\
\text { Step } 2\end{array}$ & $.35^{\star *}$ & $.35^{\star *}$ & $.31^{* *}$ & $.32^{* *}$ & .11 & .06 \\
\hline Quality change comm. & $.26^{\star *}$ & & $.24^{* *}$ & -.01 & & \\
\hline Employee participation & .13 & & .12 & $.86^{\dagger}$ & & \\
\hline Formalization climate & & -.09 & -.09 & .03 & -.00 & .04 \\
\hline Involvement climate & & $.20^{*}$ & .09 & .05 & $.36^{* *}$ & $.24^{*}$ \\
\hline $\begin{array}{l}\text { Formalization climate * } \\
\text { Quality change comm. }\end{array}$ & & & & .29 & & \\
\hline $\begin{array}{l}\text { Formalization climate * } \\
\text { Employee participation }\end{array}$ & & & & $-.85^{\dagger}$ & & \\
\hline Involvement climate * & & & & -01 & & \\
\hline Quality change comm. & & & & -.01 & & \\
\hline $\begin{array}{l}\text { Involvement climate * } \\
\text { Employee participation }\end{array}$ & & & & .08 & & \\
\hline Overall model F & $1578^{* *}$ & $13.37^{\star *}$ & $12.80^{\star \star}$ & $9.40^{* *}$ & $8.76^{\star \star}$ & $8.10^{* *}$ \\
\hline $\mathrm{R}^{2}$ & .54 & .50 & .55 & .57 & .40 & .38 \\
\hline Adjusted $\mathrm{R}^{2}$ & .51 & .47 & .51 & .51 & .36 & .33 \\
\hline $\mathrm{R}^{2}$ change & $.07^{* *}$ & $.03^{+}$ & $.08^{\star *}$ & .02 & $.08^{\star \star}$ & $.04^{*}$ \\
\hline
\end{tabular}

For organization, $1=$ largest organization and $2=$ smaller organization. For gender, $0=$ male and $1=$ female. For age, $1=<25 y, 2=26 y-35 y, 3=36 y-45 y, 4=46 y-55 y$ and $5=>55 y$.

${ }^{+} p<.10,{ }^{*} p<.05$ and ${ }^{* *} p<.01$.

VIF $<2$ for all variables. 


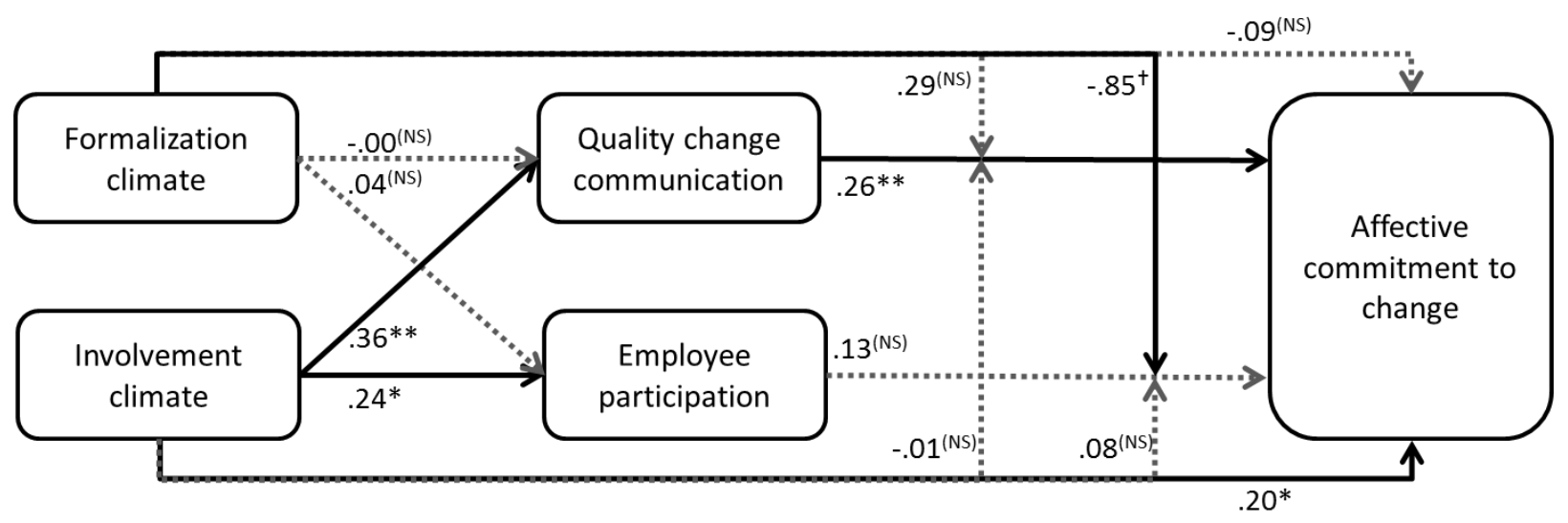

Figure 1: Path coefficients of overall model (standardized regression coefficients) 


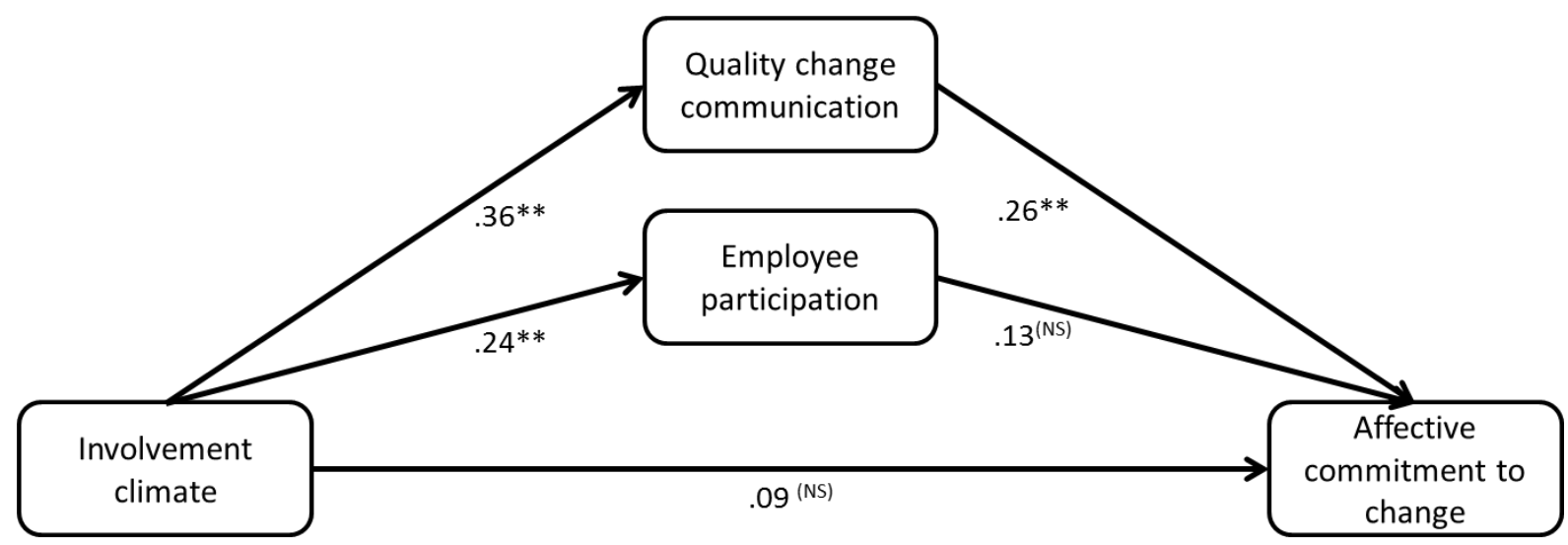

Figure 2: Path coefficients of the hypothesized mediation (standardized regression coefficients) 


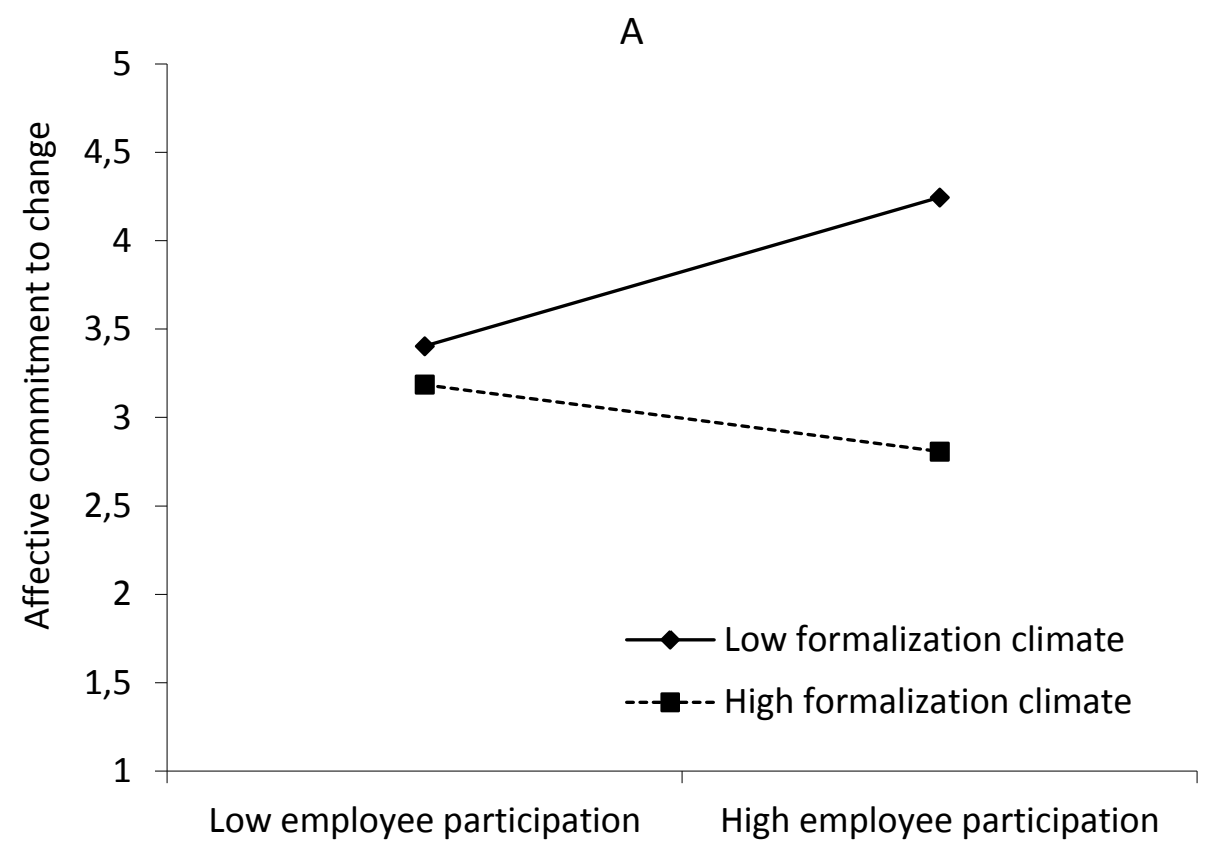

B

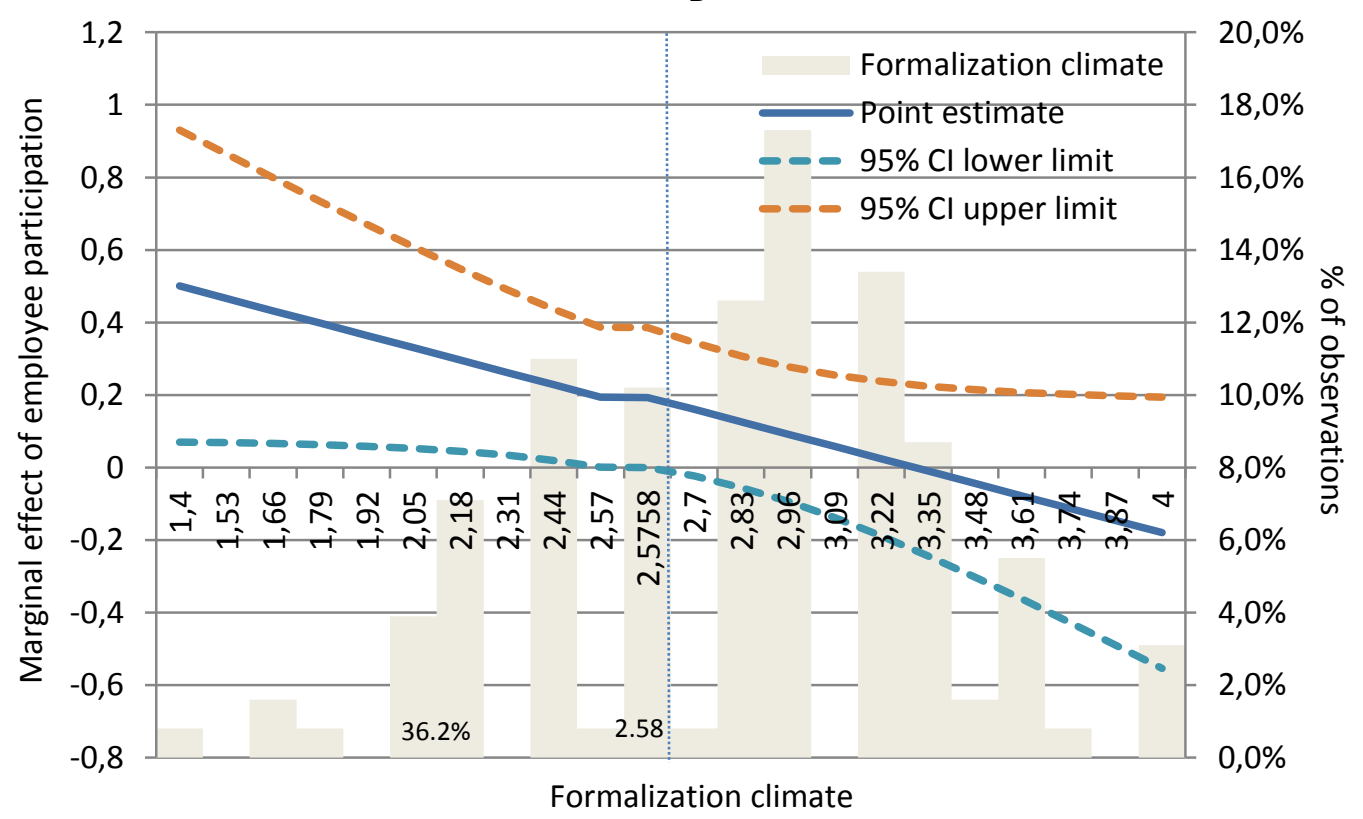

Figure 3: Affective commitment to change as a function of employee participation and formalization climate (A), and Johnson-Neyman region of significance for the conditional effect of employee participation at values of formalization climate (B). 


\section{Appendix: Items comprising variables and results of principal component analysis (varimax rotation)}

I. Change communication (adapted from Miller, Johnson, \& Grau, 1994)

I

1. The information provided to me about the changes has been timely

$.79 \quad .07$

2. The information provided to me about the changes has been useful

$.87 \quad .22$

3. The information provided to me has adequately answered my questions

$.88 \quad .20$
about the changes

4. I have received adequate information about the forthcoming changes

.87

.25

II. Employee participation (adapted from Wanberg \& Banas, 2000)

1. I participated in the implementation of the changes that have been proposed

.17 and that are occurring

2. I have exerted control over the changes that have been proposed and that are occurring

3. I have given input for the decisions being made about the future of the 